This item was submitted to Loughborough's Research Repository by the author.

Items in Figshare are protected by copyright, with all rights reserved, unless otherwise indicated.

\title{
Lessons learned practices in the engineering, procurement and construction
} sector

PLEASE CITE THE PUBLISHED VERSION

PUBLISHER

(C) Emerald Group Publishing Limited

VERSION

AM (Accepted Manuscript)

LICENCE

CC BY-NC-ND 4.0

\section{REPOSITORY RECORD}

Carrillo, Patricia M.. 2019. "Lessons Learned Practices in the Engineering, Procurement and Construction Sector". figshare. https://hdl.handle.net/2134/4192. 
This item was submitted to Loughborough's Institutional Repository (https://dspace.lboro.ac.uk/) by the author and is made available under the following Creative Commons Licence conditions.

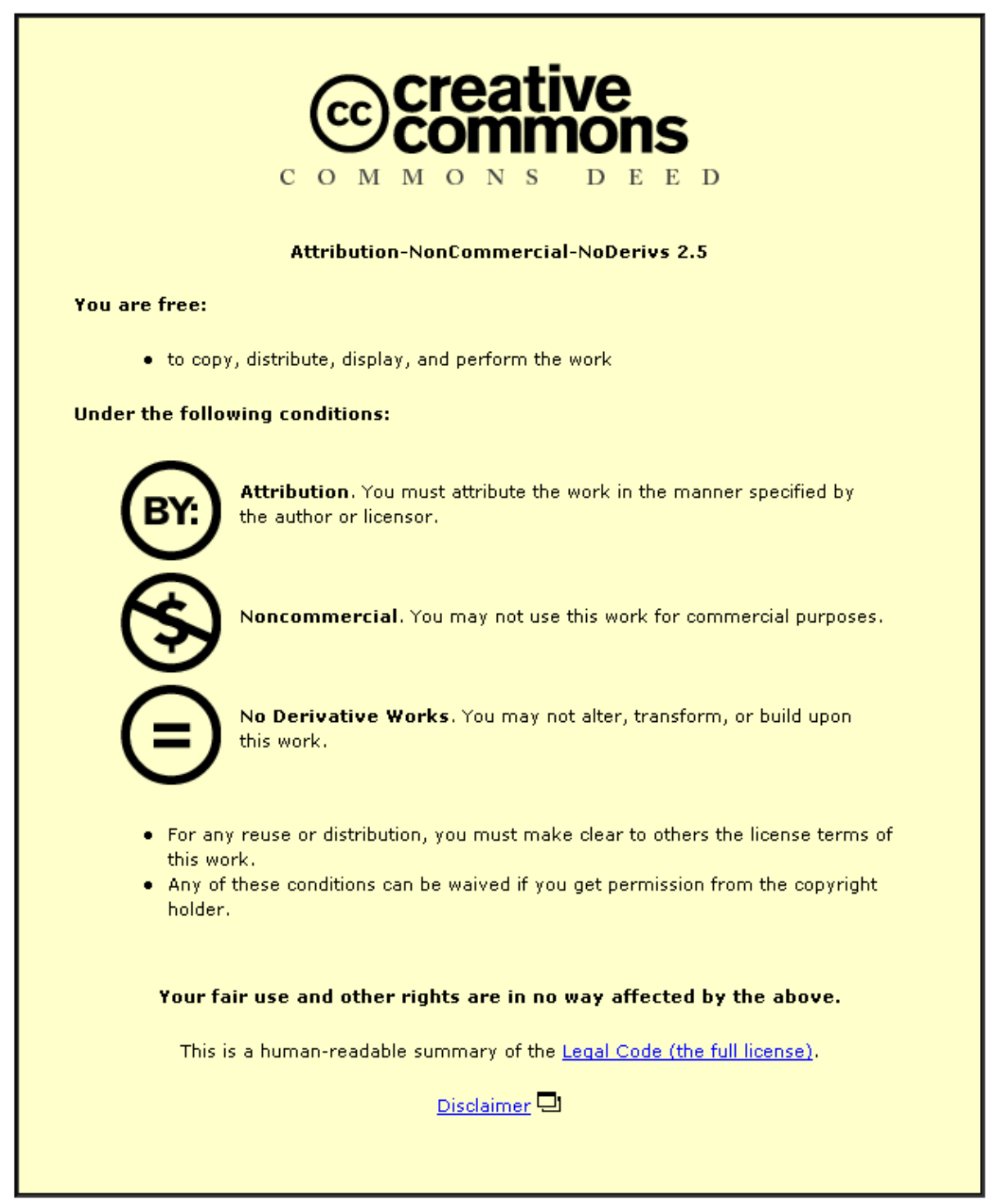

For the full text of this licence, please go to: http://creativecommons.org/licenses/by-nc-nd/2.5/ 
Lessons Learned Practices in the Engineering, Procurement and Construction sector

Patricia Carrillo

Contact Details

P.M.Carrillo@lboro.ac.uk

Department of Civil and Building Engineering

Loughborough University

Loughborough

Leicestershire LE11 3TU

UK 


\title{
Lessons Learned Practices in the Engineering, Procurement and Construction sector
}

\author{
ABSTRACT \\ The exploitation of lessons learned to improve performance on future projects is \\ highly desirable for many construction organisations. The vision of an organisation \\ that can readily recall what went well on a project and attempt to recreate those \\ successes as well as avoiding the repetition of past mistakes offers commercial \\ sense. This paper adopts a case study methodology to investigate how Canadian \\ Engineering, Procurement and Construction (EPC) companies address lessons \\ learned on their construction projects. The paper concludes with a number of \\ recommendations for UK companies regarding how the process may be improved in \\ terms of encouraging lessons learned to occur, the timing of lessons learned \\ sessions, identifying participants, the format for documenting lessons learned and \\ how these should be disseminated.
}

Keywords: lessons learned, construction, knowledge management, Alberta

\begin{abstract}
INTRODUCTION
"Most activities or tasks are not one-time events. .. Our philosophy is fairly simple: Every time we do something again, we should do it better then the last time" (BP's Group Chief Executive John Brown in Prokesch,1997). The construction industry has also recognised that although each project is unique there are some processes that are repeatable and thus there is scope to transfer learning from previous projects. This is the realm of lessons learned. Lessons learned aim to capture the positive and negative aspects of projects in order to learn from the experience thereby avoiding the repetition of mistakes which can be costly and damaging to the company's reputation. This paper therefore investigates the lessons learned practices of construction companies in Canada with the aim of identifying how lessons learned can be improved and exploited in the UK construction sector. The paper adopts a case study methodology to investigate a number of aspects of lessons learned including how it is done, who participates, the type of documentation required and how best lessons may be disseminated.
\end{abstract}

\section{LESSONS LEARNED}

Lessons learned are elements of both organisational learning and knowledge management. Senge (1994: 49) defined learning in an organisation as "the continuous testing of experience, and the transformation of that experience into knowledge - accessible to the whole organization, and relevant to its core purpose". Lessons learned therefore forms part of organisational learning because it attempts to collate lessons learned from previous projects in an effort to encourage the organisation, via its employees, to learn from past experience. Knowledge management is described as 'any process of creating, acquiring, capturing, sharing and using knowledge, wherever it resides, to enhance learning and performance in organisations' (Scarbrough et al., 1999). Lessons learned are thus also an aspect of knowledge management because it encourages the capture and dissemination of knowledge gained on past projects to enhance learning and future performance. Snider et al. (2002: 67) state "though the idea of learning from experience is timeless, formalized systems for capturing and disseminating lessons within an organisation have received increased attention in recent years." 
Lessons learned were the outcome of After Action Review (AAR) which were introduced by the US Army in the mid 1970s (Garvin, 2003). The U.S. Army (1997) defines lessons learned as "validated knowledge and experience derived from observations and historical study of military training, exercises, and combat operations". It is therefore a discussion of a project or an activity that enables the individuals involved to learn for themselves what happened, why it happened, what needs improvement and what lessons can be learned from the experience. AAR asks four leading questions:

- What did we set out to do?

- What actually happened?

- Why did it happen and

- What are we going to do next time?

AARs are not about success or failure but a mechanism that encourages people to learn from past experience. BP, one of the early adopters of knowledge management called their system Retrospect. Retrospect is a tool for 'learning after doing' (Collison and Parcell, 2001). They consider this as more in depth than an AAR and with a specific intent of capturing lessons and insights for future projects. The concept that has now been adopted in a number of organisations under a number of different names. Disterer (2002) identifies these as post-project reviews, post-project appraisals, project post-mortem, debriefing, reuse planning, reflection, corporate feedback cycle, experience factory, etc. Kleiner and Roth (1997) also introduced the term "learning histories". These allow organisations to reflect on past experience leading to effective future actions. In the UK, major companies such as BP Amoco, BAA plc, National Grid Transco and construction companies such as Bovis Lend Lease, and Buro Happold have adopted this methodology in an effort to learn from experience (DBA, 2003). DBA claims that, for construction, a learning programme can be one way to address the improvements required by the Egan agenda.

Whilst lessons learned appear to make business sense, it is the holy grail for many construction organisations. Kamara et al. (2003) and Orange et al. (1999) highlight the problems with post-project reviews which aim to capture lessons learned. It is a highly desirable activity but often does not occur for a number of reasons.

Construction projects are of a temporary nature often involving multi-disciplinary and virtual teams. There is no client requirement for lessons learned and it is logistically difficult to undertake both from a timing issue and also the complex relationships between project participants. If they occur, lessons learned take place after the project completion when project participants have transferred to new projects and, because of the project duration, the time lag between a lesson being learned and recorded is lengthy and thus may be lacking in detail. Also, the relationships and varying input from architects, engineering consultants, contractors, sub contractors and suppliers make it difficult to determine who should participate in such a process. Another challenge is deciding on what precisely is a lesson learned and how best to capture this nugget of knowledge for future use. Siemieniuch and Sinclair (1999) emphasised that the failure to capture and transfer project knowledge, especially within the context of temporary virtual organisations, leads to the increased risk of 'reinventing the wheel', wasted activity, and impaired project performance. Disterer (2002: 512) also noted that this problem was not unique to construction. He highlighted IT projects where "after finishing the project team members are spread all over the company, project documentation is stored in some folders without retaining the essentials for later use". In a study of post-project reviews of other industry, Busby (1999) found that there are a number of potential benefits and drawbacks as shown in Table 1. 


\section{Take in Table 1}

Busby (1999: 23) concluded that "post-project reviews were important learning mechanisms and their value seems to be underestimated by individuals who do not appreciate the need to disseminate insights throughout the organization". Weiser and Morrison (1998) also noted that very few firms systematically identified, captured and transferred project information for future use. They recognised the importance of sound project management where explicit knowledge in the form of drawings, standard, specifications, etc. are documented. However, they stressed that there was a need to capture knowledge on tools and methods used and stressed the importance of lessons learned to outline precise problems, describe successful and unsuccessful solutions, relevant people to contact, etc.

Love et al. (2000: 326) note that for learning to take place at organisational level, there must be processes and structures in place. They also state that in order for a construction organisation to become a learning organisation it should be skilled in:

- Systematic problem solving;

- Experimentation with new approaches;

- Learning from its own experience;

- Learning from the experience and best practice of others; and

- Transferring knowledge quickly and efficiently throughout the organisation.

It is the third, fourth and fifth items that concerns this paper - that of capturing own experience, learning from the experience of others and transferring project experience to other parties within the organisation. Collison and Parcell (2002) recommend twelve steps to capture lessons learned:

1. Call the meeting;

2. Invite the right people;

3. Appoint a facilitator;

4. Revisit the objectives and deliverables of the project;

5. Revisit the project plan or process;

6. Ask 'what went well?';

7. Find out why these aspects went well, and express the learning as advice for the future;

8. Ask 'what could have gone better?';

9. Find out what the difficulties were;

10. Ensure that the participants leave the meeting with their feelings acknowledged;

11. Determine 'what next'; and

12. Record the meeting

However, there is little advice of how the lessons learned should be stored and disseminated. This paper aims to address this important issue.

Love et al. (1999) and (DTI, 1998) stressed the importance of learning from the experience of others. With this in mind, the mechanisms adopted for lessons learned sessions by EPC companies in Alberta, Canada were investigated in order to provide learning for UK construction companies.

\section{CONSTRUCTION IN ALBERTA}

The construction market in Alberta has been buoyant for a number of years. In 2003 new projects in the province accounted for \$90.5B (£45B) (Alberta Advantage, 2004) of which oil an gas projects account for $66 \%$ of the workload (Alberta Economic Development, 2004). Many of the EPC companies' revenues are thus heavily dependent on the oil and gas sector. However, in the late 1980s, due to downturn in the economy, fewer people entered the construction industry. The current boom in 
the industry is attributed to the construction and upgrading of very large oil and gas facilities and has led to a severe shortage of both professional construction personnel and skilled operatives. It has also had an adverse impact on the industry leading to major cost and time overruns on very large, flagship projects. This has been attributed to a lack of capacity resulting in poor workmanship due to the shortage of skilled operatives and inadequate construction planning due to inexperienced staff. EPC companies now sense a changing workload. 2002 was considered by some to have been the peak of the current construction boom (CWDFC, 2003). Some EPC companies predict that construction output is about to stagnate. Oil and gas companies are delaying the start of construction on new facilities whilst they investigate the cost and time overruns and seek solutions to the problem (CWDFC,2003; COAA, 2003; Robinson Fayek et al., 2003). There is now greater competition between the EPC companies with clients demanding that EPC companies distinguish their services and demonstrate what lessons were learned from the problem projects. In addition, major clients and EPC companies believe that there is insufficient manpower available for two large, simultaneous oil and gas projects. The scale of the cost overruns have led the oil and gas clients (Construction Owners Association of Alberta - COAA) to collaborate at Vice President level, in an effort to avoid such a reoccurrence.

\section{RESEARCH METHODOLOGY AND JUSTIFICATION}

The research adopted a case study methodology to investigate how the Canadian construction sector in Alberta implemented lessons learned activities. The Alberta EPC companies were selected for a number of reasons. Firstly, Mertins et al. (2001) stated that North American companies were at the forefront of KM activities thus it was envisaged that there were some processes that could be adopted by UK companies. Secondly, the MAKE (Most Admired Knowledge Enterprises) annual surveys lists the EPC oil and gas clients as frequent finalist (Teleos and KNOW Network, 2004). It was anticipated that some of their knowledge practices, in terms of conducting lessons learned would be transferred to the EPC companies. Thirdly, it allows UK companies to undertake an external benchmark of the lessons learned activities by comparing their activities to those conducted in the same sector in another country.

A total of eight individuals in five of the largest Alberta-based companies were interviewed over a three-month period in 2003. The persons interviewed were those with overall responsibility for knowledge management and investigated lessons learned. Each interview lasted between one to two hours. The interview transcripts were then reviewed by the interviewees for accuracy.

In addition, a further four individuals were interviewed with regard to construction in Alberta in order to obtain another perspective of the construction challenges faced in the province. These were (1) the author of government reports on improving the performance of the Alberta construction sector; (2) the Executive Director of the Construction Owners Association of Alberta (COAA); (3) the Director of AEC Industry, Alberta Economic Development; and (4) an assistant professor at University of Alberta who has produced several research reports for COAA. The author mentioned above was also the President of a medium-sized EPC company. His views were sought because he was well respected by both the EPC community and academia for his understanding of the causes of problems occurring within the construction sector and his efforts to solve these at a practical level. COAA is a body that represents construction clients and has considerable influence on which construction projects to be undertaken and when. Their views were sought to obtain the client's perspective of where past projects had gone wrong, what was being done 
to address the problems and the role of lessons learned in improving project delivery. The Director of AEC was interviewed to obtain the government's perspective on the problems experienced by the construction sector and the initiatives being put in place to solve these. The academic was interviewed because of her track record of delivering reports to the COAA based on solving some of the construction challenges faced. These reports were regard as very practical and of real benefit to the industry.

\section{CASE STUDY RESULTS}

Five case study organisations were investigated to understand their lessons learned activities. The case studies investigated the companies' background to give an indication of the size of operation and to allow UK companies to benchmark their own activities. A number of aspects of lessons learned were investigated as follows:

- Requirements;

- Procedures;

- Participants;

- Documentation; and

- Dissemination.

These areas were selected because they are considered to provide an operational view of how lessons learned were conducted, the outcomes of the sessions and how they were disseminated throughout the company.

\section{Company Background}

Table 2 provides a summary of the background of the companies in terms of number of employee and annual revenue.

\section{Take in Table 2}

All five companies recognise the benefits of lessons learned to avoid the repetition of mistakes and improve communication between parties. The lessons learned sessions bring together the parties involved in the design and construction of the project in an effort to identify both successes and failures. They also recognise the role of lessons learned in the wider knowledge management context. However, only one company has a dedicated knowledge manager who is responsible for lessons learned. In the other four companies lessons learned activities form part of their quality assurance procedures.

Table 3 summarises the main details regarding the companies' lessons learned practices.

\section{Take in Table 3}

\section{Lessons Learned Requirement}

Company $\mathrm{B}$ highlighted the need for lessons learned at project close-out as early as 1994 and Company A has been undertaking lessons learned as part of its KM initiative since 2000 . The main mechanism for lessons learned is the project closeout or project post-mortem. Lessons learned form part of the Quality Assurance procedures for all projects in Companies $A, C$ and $E$. Companies $B$ and $D$ focus on large projects only (typically over $\$ 100 \mathrm{M}$ CAD) or projects that had particular problems as identified by either the client or project manager.

\section{Lessons Learned Procedure}

The procedures used vary between companies. Companies $C$ and $E$ have well structured processes whereby the project's percentage completion triggers the 
project manager to organise a project close-out meeting. Company C's Project Control System automatically changes a project status from A (Active) to A1 when a project reaches $90 \%$ completion. However, the lessons learned session may not take place for a few months after project completion when invoicing is complete. Company $\mathrm{E}$ uses the $80 \%$ completion because it believes that post-mortems should be near the end rather that at the end since (1) the key staff will move on to other projects and (2) it is difficult to remember issues that happened some time ago. Company A uses a system of stage gates to conduct lessons learned. Companies B and $\mathrm{D}$ conduct lessons learned as part of the project close-out.

\section{Lesson Learned Participants}

All the companies recognise the importance of having the team leaders of all the disciplines present at the lessons learned but this is not always possible due to other work commitments. The number of participants range from the project manager only for small projects (Company E) to 26 (Companies $B$ and D). Companies $B, D$ and $E$ sometimes invite the client to obtain their feedback. Only one company uses a trained facilitator to assist in extracting lessons learned, others use their own staff such as the Engineering Manager or Quality Manager.

An interesting format is the use of two lessons learned sessions - internal and external. The internal session tends to be more open, exposes some of the internal failings and establishes the real cause of failure. The external session, which includes the client and his representatives, tends to be more a diplomatic formality with the EPC company not wishing to expose their failings to the client.

\section{Lessons Learned Documentation}

Company A stores its lessons learned in the form of templates on its KM Library - a knowledge base of lessons learned that forms the backbone of their KM initiative. Company B captures lessons learned by brainstorming and affinity diagrams to identify the root cause of problems. Strategies for leveraging these lessons are also developed. All lessons learned are collected by the Quality Management team and are posted on a network drive in MS Word format. Company $\mathrm{C}$ records its lessons learned at the end of the project close-out report in two fields called 'Areas of Concern' and 'Opportunities for Improvement'. These are then stored on Lotus Notes and Domino. Lessons learned are also stored on their Performance Improvements Database which includes customer complaints, customer satisfaction surveys, monthly project review meetings, etc. Company D's lessons learned are published in the form of Corrective Actions. After vetting by a committee, these are then placed on the company-wide $\mathrm{I}^{3}$ database (Ideas for Improvement and Innovation) with a champion allocated to push through improvements. Company $E$ provides lessons learned in the form of bullet points with a context and a ranking order. The ranking is done based on impact on the final project outcome and how important it might be to future projects. These lessons learned are then documented in a Project Close-out Report available both on paper and a searchable electronic format.

\section{Lessons Learned Dissemination}

Company A's lessons learned are disseminated through its web-based KM Library and requires a login password for access. Company B's project managers can search for lessons learned documents based on keywords or a directory to search for similar projects or clients. Company C's use of Lotus Notes and Domino allows ready access to most employees. Also, some of their major clients conduct and store lessons learned on their own servers but this results in limited access as these are issued as paper copies and are therefore not searchable electronically.

Company $D$ uses its $I^{3}$ database but acknowledges that the context of the lessons 
learned are not sufficiently documented. Company $\mathrm{E}$ employees are able to retrieve lessons learned from paper copies of the project close-out reports or, alternatively to search for electronic copies of the document.

\section{DISCUSSION}

The drive toward performance improvement in the UK construction industry has led to companies examining their activities. Lesson learned are part of the improvement process and thus project reviews play an important part (Kululanga et al., 1998). The following section aims to highlight the strengths and weaknesses of the case study companies' practices with a view to identifying how UK companies can improve their lessons learned practices.

\section{Role of Lessons Learned In Construction}

The Alberta EPC sector are having lessons learned forced upon them from their oil and gas clients because of the problem projects. However, if they are to be undertaken they should be done thoroughly and systematically to reap benefit. Some EPC companies now use this as a means of winning work and differentiating themselves from their competitors. Indeed Company B accredits its recent success in winning projects to their ability to demonstrate that they have a procedure for conducting lessons learned and storing them on their KM Library. Major clients see this as a way of encouraging EPC companies to investigate problems on past projects and allowing them to demonstrate what systems have been designed to prevent a repetition of similar problems.

\section{Lessons Learned Requirement}

The case studies found that all five EPC companies undertook lessons learned to varying degrees. Some had imposed lessons learned on all projects whereas others used a selection criteria in terms of project size or extent of problems experienced. Two factors make this imposition relatively easy for the Canadian EPC companies. Firstly, the large scale projects procured by the oil and gas companies meant that the majority of projects undertaken would have some form of lessons learned conducted. Secondly, the quality driven processes imposed by the oil and gas clients had filtered down to the EPC companies who were starting to conduct lessons learned as part of their quality procedures. In the UK it would be logistically difficult to impose lessons learned on all projects because there is much more variety in terms of the range of clients, project size and complexity. A good practice would therefore be to conduct lessons learned on all projects over a certain value in order to understand both the positive and negative outcomes. The threshold value could be determined by each business unit. Good practice will also dictate that procedures are put in place to make sure lessons learned are included into the project programme with a named individual responsible.

\section{Lessons Learned Procedure}

Zack (1999) states that very little research has been done on identifying the appropriate lessons learned system for organisations to adopt. The case studies found a variety of mechanisms were in place. These were either lessons learned linked to stage gates or those taking place close to the end of the project. The procedures used by companies $\mathrm{C}$ and $\mathrm{E}$ are useful in that they have a project management system that triggers the timing of the lessons learned rather than waiting until the project is finished to organise lessons learned sessions.

The internal and external sessions each have their advantages and disadvantages. The internal sessions allow companies to be more open and honest about the causes of failure. The external sessions involve the client's perspective and is clearly 
valuable. However, it was widely reported that these sessions resulted in the lessons learned being sanitised, an unwillingness to recognise internal failing and was seen as a formality only. To combat this, UK companies could use internal lesson learned sessions complemented by customer satisfaction survey (if available) to address problems, particularly if they are repeat clients. The rigour with which lessons learned are undertaken and the follow-up action required are also important because there may be a temptation to 'tick the box' to indicate that a lessons learned session has taken place without resulting in organisational learning. To combat this, company guidelines should be provided as to the format of the session, what is documented and how this is to be disseminated.

\section{Lessons Learned Participants}

This is certainly an area in which the UK could adopt similar practices in terms of widening access to the lessons learned session. The active participation of all the team leaders is considered valuable to obtain a holistic view as well as different perspectives of the same problem. The on-going challenge is to get all the relevant participants around a table beyond their active involvement. The disadvantages of waiting until the end of the project to conduct lessons learned is that the key participants may be working on other projects and the importance of the lessons learned may seem diminished to those no longer actively involved in the project. One possible solution would be to conduct lessons learned periodically, rather than waiting until the end of the project. This would mirror company A's use of stage gates e.g. process protocol stages. The advantage of this is that the participants would be able to more readily recall the significance of specific lessons learned. The use of a trained facilitator is recommended to reduce the blame culture and to help draw out and document relevant lessons in an unbiased, blame-free manner.

\section{Lessons Learned Documentation}

This is an area of concern and covers two main areas: (1) how the lessons learned are recorded; and (2) the resulting actions. Amongst the EPC companies little guidance was provided on the format or contents of the lessons learned. There must be a structured format in which to document the lessons learned with a number of key attributes such as the context, the level of detail, the project participants, contact details, recommendations, responsibility, etc. In addition, this must be accessible and searchable either as hard copies or electronically on an intranet. A template could be designed to ensure uniformity in how lessons learned are documented and the level of detail provided. This should be aimed at what future users regard as relevant knowledge before starting a project. Also, the actions generated by the lessons learned need to adhere to a process to ensure that there are validated as relevant to future projects, and supported by a list of actions, with responsibilities and timelines allocated.

\section{Lessons Learned Dissemination}

Another failure in lessons learned is that there is no systematic way of disseminating lessons learned. Companies acknowledged that this is done in an adhoc manner due to the different formats of recording lessons learned. Some companies have lessons learned in a paper format as part of the overall project documentation. This downplays the significance of the lessons learned and makes it difficult for project managers to review relevant lessons. Some companies have stored their lessons learned electronically but the mechanism for informing staff that these are available and indeed the format of these documents makes it difficult to conduct searches.

The importance of lessons learned is diminished if they are not publicised or not readily accessible to employees. A recommendation for UK companies would be to 
ensure that lessons learned are captured and stored electronically in a standard template that contain attributes that can readily searched. In addition, the existence of lessons learned should be pushed to project teams. This can be in an abbreviated form, for example a list of keywords so that users can choose to ignore the alert if it is of little interest or drill deeper for additional information if it is deemed relevant.

\section{Incentives for Lessons Learned}

Only Company $\mathrm{E}$ has a formal requirement for project managers to search for Lessons Learned. Their Quality Managers would ensure that the project procedures highlight the need for the project manager to review lessons learned from previous projects at the start of the project. Lessons learned will only bring benefit if they are used on future projects to encourage good practice or to avoid problems. This makes it all the more important for these lessons to be available in a searchable format. The difficult issue remains how to demonstrate that lessons learned have added value. Only Company A was able to do this in an anecdotal manner. They believe that recent projects have been won on the basis of their lessons learned system. What is clear is that their clients are now demanding that lessons learned are undertaken in order to win future work and it is now part of their business process.

\section{CONCLUSIONS}

Lessons learned is considered the holy grail amongst construction companies. Many recognise the benefits of disseminating good practice as well as ways of avoiding the repetition of mistakes. However, it is logistically difficult to conduct lessons learned at the end of the project when project teams have dispersed and moved onto other projects. Even if lessons learned sessions are conducted the question arises as to who should participate, and how they are documented and disseminated.

This paper investigated the practices of five Canadian EPC companies to explore their mechanisms for conducting lessons learned with a view of making recommendations to UK companies. The main areas of lessons learned investigated were (1) the requirement to conduct lessons learned sessions; (2) the procedures for conducting lessons learned; (3) the participants involved; (4) the documentation required; and (5) dissemination mechanisms. Exploring these areas have highlighted several ways in which UK construction firms could improve their lessons learned procedures to ensure that they are conducted more thoroughly and systematically:

- Conduct lessons learned for all projects over a prescribed value determined by the business unit and particularly for complex projects where there is a large learning element;

- Conduct lessons learned periodically, preferably linked to project stage gates to ensure that the significance of the lesson learned does not diminish with time or is lost because key employees are no longer involved with the project;

- Conduct lessons learned with all team leaders and the supply chain to obtain different perspectives of the problem and to make sure that the root cause of problems are discussed openly and honestly. A trained facilitator is recommended to draw out problems that may cause confrontation;

- A standard template should be used to document lessons learned to ensure consistency across all projects. These should be indexed and stored electronically to facilitate ready access;

$\$$ Intranets should be used to push alerts of the availability of lessons learned with the facility to drill deeper if required; and 
$\$$ Team leaders and project managers should be required to search for lessons learned on relevant past projects before the start of new projects.

Lesson learned, both positive and negative, do have a role to play in continuous improvement. The challenge is to make lessons learned more systematic so that it becomes part of the business process and impose a structure to what is currently done on an adhoc basis. With these in place companies can build a database of useful knowledge to ensure that future projects benefit from these lessons.

Acknowledgements: The author wishes to thank the Royal Academy of Engineering for funding this study, the Project Management Specialization Unit, Department of Civil Engineering, University of Calgary for hosting the research secondment and numerous EPC companies and individuals in Alberta who have contributed to this study. 


\section{REFERENCES}

Alberta Advantage, (2004), "Inventory of Major Alberta Projects", available at http://www.alberta-canada.com/statpub/mp0405.cfm.

Alberta Economic Development, (2004), "Oil Sands Industry Update". Alberta Economic Development, May 2004, available at http://www.albertacanada.com/oandg/pdf/oilsands_mar2004.pdf.

Alberta Economic Development, (2004), "Oil Sands Industry Update", available on the internet at: http://www.albertacanada.com/oandg/pdf/oilsands mar2004.pdf

Busby, J.S., (1999), "An Assessment of Post-Project Reviews". Project Management Journal. 30(3), pp. 23-29.

COAA, (2003), Effective Integration of Apprentices: A Pilot Study, University of Alberta and Construction Owners Association of Alberta.

Collinson, C. and Parcell, G., (2001), Learning to Fly, Capstone Publishing Limited, Oxford.

CWDFC, (2003), Supply and Demand Forecast 2003-2007 Summary Report, Construction Workforce Development Forecasting Committee, May 2003.

DBA, (2003), Learning from experience, David Bartholomew Associates.

Department of the Army, (1993), "A Leader's Guide to After Action Reviews". Training Circular 25-20., available at http://www.au.af.mil/au/awc/awcgate/army/tc_25-20

Department of Trade and Industry (DTI), (1998) "Competitiveness White Paper: Building the Knowledge Driven Economy" at http://www.dti.gov.uk/comp/competitive/

Disterer, G., (2002), "Management of project knowledge and experiences", Journal of Knowledge Management. 6(5), pp. 512-520.

Garsden, B.R., (1995), "Postconstruction evaluation", Journal of Construction Engineering and Management, 121(1), pp. 37-42.

Garvin, D.A., (2003), Learning in Action: A Guide to Putting the Learning Organization to Work, Harvard Business School Press, Massachusetts.

Kamara, J. M., Anumba, C. J., Carrillo, P. M. and Bouchlaghem, N., (2003), "Conceptual framework for live capture and reuse of project knowledge," in Amor, R. (ed.) Construction IT: Bridging the Distance. Proceedings of the CIB W78's $20^{\text {th }}$ International Conference on Information Technology for Construction, New Zealand, 23-25 April, pp. 178-185.

Kleiner, A. and Roth, G. (1997), "How to make experience your company's best teacher", Harvard Business Review, September-October, pp. 173-177.

Kululanga, G.K., McCaffer, R., Price, A.D.F. and Fotwe-Edum, F., (1999), "Learning Mechanisms employed by construction contractors", Journal of Construction Engineering and Management, 125(4), pp. 215-223.

Love, P.E.D., Heng, L., Irani, Z. and Faniran, O., (2000), "Total Quality Management and the learning organization: a dialogue for change in construction", Construction Management and Economics, 18(3), pp. 321-331.

McTague, B. and Jergeas, G., (2002), "Productivity Improvements on major Alberta Construction projects", May 2002, Alberta Economic Development.

Mertins, K., Hesig P. and Vorbeck, J., (2001), Knowledge Management: Best Practices in Europe, Springer-Verlag, Berlin.

Mumford, A., (1995), "Four approaches to learning from experience", Industrial and Commercial Training, 27(8), pp. 12-19.

Orange, G., Burke, A. and Cushman, M., (1999), "An approach to support reflection and organisational learning within the UK construction industry", Paper presented at BITWorld'99: Cape Town, SA, 30 June-2 July (http://is.Ise.ac.uk/bhive) 
Prokesch, S.E., (1997), "Unleashing the Power of Learning: An Interview with British Petroleum's John Browne”. Harvard Business Review, September-October, pp. 147-168.

Robinson Fayek, A., Dissanayake, M. and Campero, O., (2003), Measuring and Classifying Construction Field Rework: A Pilot Study, Construction Owners Association of Alberta.

Scarborough, H., Swan, J., and Preston, J., (1999), Issues in People Management: Knowledge Management: A Literature Review, Institute of Personnel and Development, The Cromwell Press, Wiltshire.

Senge, P., (1994), The Fifth Discipline: the Art and Practice of a Learning Organisation, Nicholas Brealey Publishing Limited, London.

Siemieniuch, C. E. and Sinclair, M. A., (1999), Organisational Aspects of Knowledge Lifecycle Management in Manufacturing, International Journal of HumanComputer Studies, Vol. 51: pp. 517-547.

Snider, K.F., Barrett, F.J. and Tenkasi, R., (2000), "Considerations in acquisition Lessons-Learned System design", Acquisition Review Quarterly, Winter, pp. 67-84.

Teleos and the KNOW Network, (2004), "2003 Global Make Admired Knowledge Enterprises", available at http://www.knowledgebusiness.com/knowledgebusiness/upload/2003_GlobalM AKE_Summary.pdf

U.S. Army, (1997), "Centre for Army lessons learned handbook", 97-13. U.S. Army, Fort Leavenworth.

Weiser, M. and Morrison, J., (1998), "Project memory: information management for project teams", Journal of Management Information Systems, 14(4), pp. 149166.

Zack, M.H., (1999), “Developing knowledge”. California Management Review. 41(3), pp. 127-145. 
Table 1: Benefits and Drawbacks of Post Project Reviews (Busby,1999)

Benefits

- Allows employees to assemble the different experiences and draw coherent conclusions

- It allows employees to consult others to know the outcome of their performance

- What employees learn from doing a project is disseminated to others who may have to do similar tasks in the future
Drawbacks

- They take time which means it incurs a cost. The beneficiaries are future projects, not the current one

- Reviews involve looking back at potentially embarrassing situations

- Employees are reluctant to engage in activities that lead to blame, criticism or recrimination

- Many people believe that you learn from your own experience and that others without that experience cannot learn from it 
Table 2: Company Background

\begin{tabular}{clcr}
\hline Company & \multicolumn{1}{c}{ Interviewee(s) } & $\begin{array}{c}\text { Number of } \\
\text { Employees }\end{array}$ & $\begin{array}{c}\text { Annual } \\
\text { Revenue } \\
(\$ M C A D)\end{array}$ \\
\hline A & $\begin{array}{l}\text { Manager Organizational Excellence; } \\
\text { Knowledge Systems Manager; Senior Vice }\end{array}$ & 1,500 & $\$ 200$ \\
& $\begin{array}{l}\text { President; Change Manager } \\
\text { B }\end{array}$ & $\begin{array}{l}\text { Director, Quality \& Work Process } \\
\text { Improvement }\end{array}$ & $1,400^{*}$ \\
C & Manager, Quality Assurance & 1089 & $\$ 1,622^{*}$ \\
D & Division Quality Manager & 800 & $\$ 350$ \\
E & Manager, Human Resources & 300 & $\$ 200$ \\
\hline
\end{tabular}

* Alberta employees and revenue only, globally there are 15,000 employees and \$3.4B CAD revenue. 
Table 3: Lessons Learned Practices

\begin{tabular}{|c|c|c|c|c|c|}
\hline Company & $\begin{array}{l}\text { Lessons Learned } \\
\text { Requirement }\end{array}$ & $\begin{array}{l}\text { Lessons Learned } \\
\text { Procedure }\end{array}$ & $\begin{array}{l}\text { Lessons Learned } \\
\text { Participants }\end{array}$ & $\begin{array}{l}\text { Lessons Learned } \\
\text { Documentation }\end{array}$ & $\begin{array}{l}\text { Lessons Learned } \\
\text { Dissemination }\end{array}$ \\
\hline$A$ & $\begin{array}{l}\text { Completed for all new } \\
\text { projects. Part of Quality } \\
\text { Assurance procedures }\end{array}$ & $\begin{array}{l}\text { Linked to four process gates. } \\
\text { Trained facilitator used. LL* } \\
\text { reviewed by Continuous } \\
\text { Improvement Committee }\end{array}$ & $\begin{array}{l}\text { Consists of all team leads for } \\
\text { the various disciplines }\end{array}$ & $\begin{array}{l}\text { Standard template used to } \\
\text { record problem } \\
\text { characteristics and } \\
\text { opportunities. A checklist of } \\
\text { process improvements } \\
\text { created with timelines and } \\
\text { responsibilities }\end{array}$ & $\begin{array}{l}\text { Placed on 'KM Library' for } \\
\text { access by login }\end{array}$ \\
\hline$B$ & $\begin{array}{l}\text { Completed for large projects } \\
\text { only (over } \$ 100 \mathrm{M} \text { CAD) }\end{array}$ & $\begin{array}{l}\text { Project Managers trigger LL } \\
\text { process as part of project } \\
\text { close-out. Two meetings } \\
\text { held - internal and external. } \\
\text { Uses brainstorming and } \\
\text { affinity diagrams to capture } \\
\text { LL. External facilitator } \\
\text { sometimes used. }\end{array}$ & $\begin{array}{l}\text { All project leads e.g. Project } \\
\text { Manager, Project Engineer, } \\
\text { Project Quality Manager }\end{array}$ & $\begin{array}{l}\text { Meeting minutes recorded on } \\
\text { MS Word in varying formats }\end{array}$ & $\begin{array}{l}\text { Searchable Word document } \\
\text { posted on shared network } \\
\text { drive }\end{array}$ \\
\hline $\mathrm{C}$ & $\begin{array}{l}\text { Completed for all Projects. } \\
\text { Part of Quality Assurance } \\
\text { procedures }\end{array}$ & $\begin{array}{l}90 \% \text { project completion } \\
\text { triggers action by Project } \\
\text { Manager. LL session occurs } \\
\text { a few months after project } \\
\text { completion. LL forms item on } \\
\text { Agenda. Normally internal } \\
\text { meetings, except for } \\
\text { alliances }\end{array}$ & $\begin{array}{l}\text { All senior project staff and } \\
\text { the Manager of Operations } \\
\text { e.g. Managers of } \\
\text { Engineering, Materials } \\
\text { Management, Project } \\
\text { Control, and QA Manager }\end{array}$ & $\begin{array}{l}\text { Part of project close-out } \\
\text { report with two fields - areas } \\
\text { of concern and opportunities. } \\
\text { LL stored on Lotus Notes } \\
\text { and Domino. }\end{array}$ & $\begin{array}{l}\text { Uses Lotus Notes and } \\
\text { Domino. Forms part of } \\
\text { Performance Improvement } \\
\text { Database. Available for } \\
\text { most employees. Attempts } \\
\text { to get project teams together }\end{array}$ \\
\hline $\mathrm{D}$ & $\begin{array}{l}\text { Completed for large projects } \\
\text { only. Decision of client, } \\
\text { Project Manager and } \\
\text { Manager of Projects. } \\
\text { Biased towards problem } \\
\text { projects }\end{array}$ & $\begin{array}{l}\text { Part of project post-mortem } \\
\text { over a two period }\end{array}$ & $\begin{array}{l}\text { All discipline leads. Client } \\
\text { sometimes invited }\end{array}$ & $\begin{array}{l}\text { Post-mortem report with } \\
\text { lessons learned published as } \\
\text { 'Corrective Actions' }\end{array}$ & $\begin{array}{l}I^{3} \text { database (Ideas for } \\
\text { Improvement and } \\
\text { Innovation) used }\end{array}$ \\
\hline$E$ & $\begin{array}{l}\text { Completed for all projects as } \\
\text { part of Quality Assurance } \\
\text { procedures }\end{array}$ & $\begin{array}{l}\text { Project Manager alone does } \\
\text { the LL for small projects. For } \\
\text { large projects } 80 \% \\
\text { completion triggers a post- } \\
\text { mortem. Two post-mortems } \\
\text { held - internal and external } \\
\text { (with client). Internal } \\
\text { facilitators used. }\end{array}$ & $\begin{array}{l}\text { Engineering Manager, } \\
\text { Quality Manager and key } \\
\text { staff }\end{array}$ & $\begin{array}{l}\text { LL are prioritised in order of } \\
\text { impact on the final project } \\
\text { outcome and how important } \\
\text { it might be to future projects. } \\
\text { Forms part of project close- } \\
\text { out report }\end{array}$ & $\begin{array}{l}\text { Available in paper format as } \\
\text { well as searchable electronic } \\
\text { format }\end{array}$ \\
\hline
\end{tabular}

* $\mathrm{LL}=$ lessons learned 
